\title{
Synthesis and Chromatographic Characteristics of Multidentate Ligand-Boned Silica Stationary Phases
}

\author{
Rong Li, ' Yan Wang, Guo-Liang Chen, Mei Shi, Xiao-Gang Wang, and Jian-Bin Zheng ${ }^{\dagger}$ \\ School of Chemical Engineering, Northwest University, North Taibai Road 229, Xi'an 710069, P. R. China \\ ${ }^{*}$ E-mail:lhr40222@tom.com \\ $\dagger$ Institute of Analytical Science, Northwest University, North Taibai Road 229, Xi'an 710069, P. R. China \\ Received May 9, 2010, Accepted June 9, 2010
}

\begin{abstract}
To improve the separation property and stability of metal chelate $\mathrm{Cu}$ (II) column, three new kinds of multidentate aminocarboxy silica columns with cation-exchange properties were synthesized using glutamic acid (Glu), glutamic acidbromoacetic acid (Glu-BAA), glutamic acid-bromosuccinic acid (Glu-BSUA) as ligands and silica gel as matrix. The standard proteins were separated with prepared chromatographic columns. The stationary phases exhibited the metal chelate property after fixing copper ion (II) on the synthesized multidentate ligand silica columns. The binding capacity of immobilized metal ion was related with the dentate number of multidentate ligands. Chromatographic behavior of proteins and the leakage of immobilized metal ion on multidentate chelate $\mathrm{Cu}$ (II) columns were affected by the dentate number of multidentate ligands and competitive elution system directly. The results showed that quinquedentate Glu-BSUA-Cu(II) column exhibited better chromatographic property and stability as compared with tridentate Glu-Cu(II) column, tetradentate Glu-BAA-Cu(II) column and commonly used IDA-Cu(II) column.
\end{abstract}

Key Words: Cation-exchange, Metal chelate, Multidentate ligand, Binding capacity, Leakage

\section{Introduction}

Immobilized metal affinity chromatography (IMAC) has been favored by bio-chromatography scientists since it has more advantages as compared with other affinity chromatographic modes. ${ }^{1}$ Over the past three decades, IMAC has become an essential tool for the identification, detection, isolation and purification of proteins, especially been active in the areas such as proteomics, ${ }^{2-5}$ refolding of recombinant proteins, ${ }^{6-9}$ labeling and identification of proteins ${ }^{5,10-12}$ as well as cancer diagnosis ${ }^{13-16}$ in recent few years. Ion exchangers using aminocarboxy chelating agent as ligand have been widely used in IMAC., ${ }^{9-23}$ Iminodiacetic acid (IDA) is one of the most commonly used ligands. The characteristics of this sorbent are (1) IDA without immobilized metal ion can be used as cation exchanger to separate positively charged proteins. (2) IDA with metal ion can be used as metal chelate column to isolate proteins with the affinity for metal ions. When transition metal ion, e.g., $\mathrm{Ni}^{2+}$, $\mathrm{Co}^{2+}$ or $\mathrm{Zn}^{2+}$, is immobilized to IDA chelating agent, a weak affinity metal chelate column with cation-exchange characteristics is formed. Adsorbed proteins on the column can be easily separated by increasing the ionic strength in phosphate buffer (PB). A typical strong affinity metal chelate column is obtained when IDA ligand is fixed with $\mathrm{Cu}^{2+}$. It is difficult to elute proteins adsorbed on IDA-Cu(II) column with $\mathrm{PB}-\mathrm{NaCl}$ buffer. The elution of proteins on the column can be achieved only by adding competitive agent in solution or decreasing the $\mathrm{pH}$ of the solution. ${ }^{24}$ However, the disadvantages of this approach are insufficient separation for proteins and more serious leakage of $\mathrm{Cu}^{2+}$ under competitive elution conditions. As a result, the column has shorter lifetime and poor reproducibility, the products and detector will be polluted, and the measurement even can not be performed. ${ }^{25}$ Therefore, the popularization and application of metal chelating $\mathrm{Cu}(\mathrm{II})$ column have been seriously affected.

According to the mechanism of metal chelate coordination, the authors believe that we should study starting with complex ligands, the dentate number of ligands and competitive agents in order to improve the selectivity and stability of metal chelate $\mathrm{Cu}$ (II) column. In this work, tridentate Glu-silica, tetradentate Glu-BAA-silica and quinquedentate Glu-BSUA-silica stationary phases were synthesized using Glu, Glu-BAA, Glu-BSUA as ligands and silica gel as matrix. The cation-exchange properties of proteins on Glu-silica, Glu-BAA-silica and Glu-BSUA-silica columns were investigated. The effect of the dentate numbers of complex ligands on the binding capacity of $\mathrm{Cu}^{2+}$ was studied. The leakage of $\mathrm{Cu}^{2+}$ and the separation of proteins on metal chelate columns with different dentate numbers were examined under competitive elution conditions.

\section{Experimental}

Reagents and chemicals. Silica gel $(7 \mu \mathrm{m}, 300 \AA)$ was obtained from Lanzhou Institute of Chemical Physics of the Chinese Academy of Sciences (Lanzhou, China). $\gamma$-Glycidoxypropyltrimethoxysilane ( $\gamma$-GLDP) was purchased from Gaixian Chemical Engineering Institute (Liaoning, China). Glutamic acid (Glu), bromoacetic acid (BAA) and bromosuccinic acid (BSUA) were purchased from Shanpu Chemical Engineering Company (Shanghai, China). Imidazole (Imid), glycine (Gly) and the other reagents were of analytical grade and purchased from Xi'an Chemical Reagent Company (Xi'an, China). Cytochrome-C (Cyt-C), lysozyme (Lys) and ribonuclease (RNase) were purchased from Sigma Company (St. Louis. Mo., USA). Bovine 
serum albumin (BSA) was obtained from Biochemical Reagent Company (Shanghai, China). $2.0 \mathrm{mg} / \mathrm{mL}$ protein mixture of BSA, RNase, Cyt-C and Lys were prepared with $20 \mathrm{mM}$ PB (pH 6.0).

Apparatus. ÄKTA purifier 10 (Amersham Biosciences, Sweden) was used for chromatographic experiments. Atomic absorption spectrometry TAS-986 (Puxi General Apparatus Co., Ltd., China) was used for determining binding capacities and leakages of $\mathrm{Cu}^{2+}$. Potentiometer TitraMate 20 (Mettler Toledo, Switzerland) was used for adjusting the $\mathrm{pH}$ of the solutions. Slurry packed apparatus 124PP (Chemico, Japan) was used for column packing.

Synthesis of epoxy-activated silica. Epoxy-activated silica was synthesized in acetate-acetic acid buffer (NaAc-HAc, $\mathrm{pH}$ 4.0 ) according to the procedure in reference. ${ }^{26} 2.0 \mathrm{~g}$ dried silica gel was added to $40 \mathrm{~mL}$ of $0.1 \mathrm{M} \mathrm{NaAc}-\mathrm{HAc}$ buffer ( $\mathrm{pH} 4.0$ ), followed by the addition of $2.0 \mathrm{~mL} \gamma$-GLDP. The reaction was carried out at $90{ }^{\circ} \mathrm{C}$ for $2 \mathrm{~h}$ with stirring. The obtained epoxy silica was washed with water until neutral $\mathrm{pH}$.

Synthesis of Glu-silica stationary phase. $1.5 \mathrm{~g}$ of Glu was added to $30 \mathrm{~mL}$ of $1 \mathrm{M}$ sodium carbonate $\left(\mathrm{Na}_{2} \mathrm{CO}_{3}\right)$. The $\mathrm{pH}$ of the solution was adjusted to 8.5 followed by the addition of $2.0 \mathrm{~g}$ dried epoxy silica gel. The reaction was carried out at $65^{\circ} \mathrm{C}$ for $12 \mathrm{~h}$ with stirring. The obtained Glu-silica was washed successively with water, $10 \%$ acetic acid and water again until neutral $\mathrm{pH}$.

Synthesis of Glu-BAA-silica stationary phase. $5.0 \mathrm{~g}$ of BAA was added to $\mathrm{Na}_{2} \mathrm{CO}_{3}$ solution. The $\mathrm{pH}$ of the solution was adjusted to 8.5 with $2 \mathrm{M} \mathrm{NaOH}$ on an ice bath, followed by the addition of $2.0 \mathrm{~g}$ Glu-silica. The reaction was carried out at $25{ }^{\circ} \mathrm{C}$ for $24 \mathrm{~h}$ with stirring. The resulted Glu-BAA-silica was washed successively with water, $10 \%$ acetic acid and water again until neutral $\mathrm{pH}$.

Synthesis of Glu-BSUA-silica stationary phase. $5.0 \mathrm{~g}$ of BSUA was added to $\mathrm{Na}_{2} \mathrm{CO}_{3}$ solution. The synthesis of GluBSUA-silica was carried out according to the procedure for the preparation of Glu-BAA-silica.

Column packing. Synthetic stationary phases were packed into $100 \times 4.6 \mathrm{~mm}$ I.D. stainless-steel columns under $40 \mathrm{MPa}$ pressure.

Immobilization of metal ion. Adopting dynamic chelate method, the packed Glu-silica, Glu-BAA-silica and Glu-BSUAsilica columns $(100 \times 4.6 \mathrm{~mm}$ I.D. $)$ were connected to the chromatographic system respectively, and then perfused with 50 $\mathrm{mM}$ copper sulfate in $10 \mathrm{mM} \mathrm{NaAc-HAc}(\mathrm{pH}$ 5.0) at the flow rate of $0.5 \mathrm{~mL} / \mathrm{min}$ until saturation. Unbonded copper was washed out with water and $20 \mathrm{mM}$ PB, successively (detection with $\mathrm{Na}_{2} \mathrm{~S}$ ).

Determination of binding capacities for immobilized metal ion. Metal copper ions (II) immobilized to multidentate chelate columns were eluted with $50 \mathrm{mM}$ EDTA-2Na. The eluates were collected into $50 \mathrm{~mL}$ volumetric flasks and then diluted to the scale with water. The total concentrations of $\mathrm{Cu}^{2+}$ in the diluted eluates were determined by atomic absorption spectrophotometry (AAS) using EDTA-2Na as a blank solution. Binding capacity of $\mathrm{Cu}^{2+}$ (q, $\mu \mathrm{mol} / \mathrm{g}$ silica) was calculated by the following equation: $q=C \cdot V / M \cdot m$, where $C$ is the total concentration of $\mathrm{Cu}^{2+}(\mu \mathrm{g} / \mathrm{mL}), V$ is volume of volumetric flask $(50 \mathrm{~mL})$,
$M$ is molecular weight of copper (63.55), $m$ is mass of multidentate ligand silica stationary phase $(\mathrm{g})$.

Determination of leakages for immobilized metal ion. Metal copper ions (II) immobilized to multidentate chelate columns were eluted by gradient elution with the selected competitive systems. The eluates were collected into $50 \mathrm{~mL}$ volumetric flasks and then diluted to the scale with water. The leakage concentrations of $\mathrm{Cu}^{2+}$ in the diluted eluates were determined by AAS using individual competitive eluant as a blank solution. Leakage rate of $\mathrm{Cu}^{2+}(\mathrm{r}, \%)$ was calculated by the following equation: $r=C_{0} / C \times 100$, where $C_{0}$ is the leakage concentration of $\mathrm{Cu}^{2+}(\mu \mathrm{g} / \mathrm{mL})$.

Chromatographic experiments. The cation-exchange properties of proteins on Glu-silica, Glu-BAA-silica and Glu-BSUAsilica columns were investigated in $\mathrm{PB}-\mathrm{NaCl}$ system, respectively. The leakages of $\mathrm{Cu}^{2+}$ and the separation properties of proteins on Glu-Cu(II), Glu-BAA-Cu(II) and Glu-BSUA-Cu(II) columns with different dentate numbers were studied in different competitive elution systems, respectively. All the chromatographic experiments were performed in accordance with liner gradient elution.

\section{Results and Discussion}

Synthesis of multidentate ligand silica stationary phases. Multidentate ligand stationary phases consist of silica gel used as matrix, $\gamma$-GLDP as spacer arm and ligands. Spacer arm can activate matrix, improve the space freedom of the interaction between ligand and proteins, and regulate the hydrophilicity of stationary phase. In this experiment, spacer arm was attached to silica gel via siloxane and to the amino-group of ligand via epoxy group. Tridentate Glu-silica packing was firstly synthesized by using Glu as ligand. Then, tetradentate Glu-BAAsilica and quinquedentate Glu-BSUA-silica packings were obtained by Glu-silica bonded with BAA and the BSUA, respectively.

\section{Synthesis of Glu-silica stationary phases.}

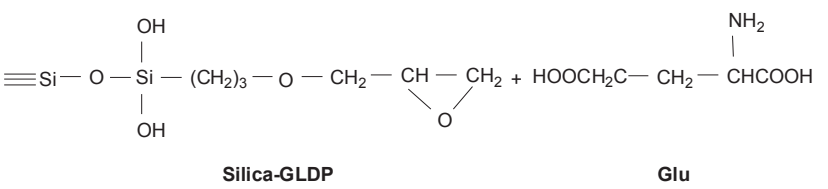

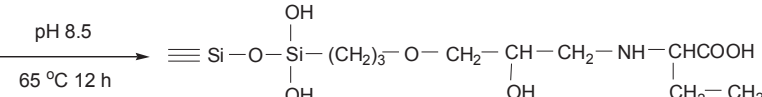

$$
\begin{aligned}
& \mathrm{OH} \quad \mathrm{OH} \quad \mathrm{CH}_{2}-\mathrm{CH}_{2} \mathrm{COOH} \\
& \text { Glu-Silica }
\end{aligned}
$$

Synthesis of Glu-BAA-silica stationary phases.

$$
\begin{aligned}
& \mathrm{OH} \\
& \equiv \mathrm{Si}-\mathrm{O}-\mathrm{S} \mathrm{S}-\left(\mathrm{CH}_{2}\right)_{3}-\mathrm{O}-\mathrm{CH}_{2}-\mathrm{CH}_{\mathrm{l}}-\mathrm{CH}_{2}-\mathrm{NH}-\mathrm{CHCOOH}+\mathrm{BrCH}_{2} \mathrm{COOH} \\
& \mathrm{OH} \quad \mathrm{OH} \quad \mathrm{CH}_{2}-\mathrm{CH}_{2} \mathrm{COOH} \\
& \text { Glu-Silica } \quad \text { BAA }
\end{aligned}
$$

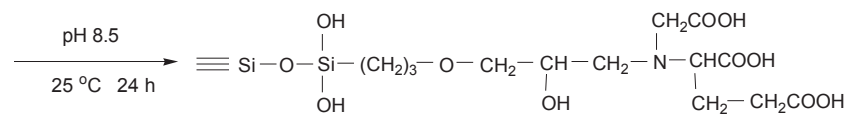

Glu-BAA-Silica 
Synthesis of Glu-BSUA-silica stationary phases.<smiles>C#[Si]O[Si](O)(O)CCOCC(O)CNC(CCC(=O)O)C(=O)OCC(O)C(=O)O</smiles>

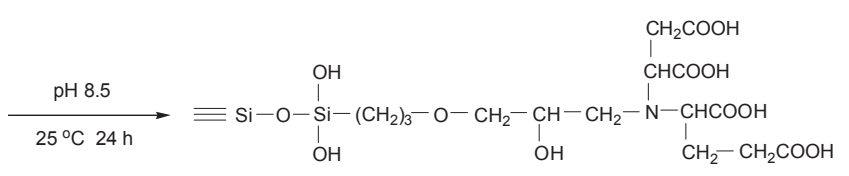

Glu-BSUA-Silica

Chromatographic behavior of proteins on multidentate ligand silica stationary phases. Fig. 1 displays chromatograms of proteins on multidentate ligand bonded-silica columns prepared according to above reactions. As seen in Fig. 1, although the dentate numbers of three ligands were different, standard protein mixture could be effectively separated under the same chromatographic conditions. Furthermore, the elution orders of proteins on three columns were consistent, that is, acidic protein BSA (pI 4.9) was not retained, basic proteins, RNase (pI 8.7), Cyt-C (pI 10.1) and Lys (pI 11.0), were eluted in the order of an increase in isoelectric point $(\mathrm{pI})$. The results showed that three kinds of multidentate ligand bonded-silica columns displayed the electrostatic interaction characteristics with cationexchange properties.

Bonding of $\mathrm{Cu}^{2+}$ on multidentate chelate columns. Glu, GluBAA and Glu-BSUA contain three, four and five coordination atoms, which can form the cyclic compound with transition metal $\mathrm{Cu}^{2+}$, respectively. When the coordination number of $\mathrm{Cu}^{2+}$ is six, tridentate Glu, tetradentate Glu-BAA and quinquedentate Glu-BSUA will form variable octahedral structures with $\mathrm{Cu}^{2+}$ in asymmetrical coordination field as the result of Jahn-Teller effect (Fig. 2).

To demonstrate the relationship between the dentate number of ligands and the coordination strength with $\mathrm{Cu}^{2+}$, the effect of ligands with different dentate numbers on the binding capacity of $\mathrm{Cu}^{2+}$ was examined in NaAc-HAc buffer system. Binding capacities of $\mathrm{Cu}^{2+}$ on Glu-silica, Glu-BAA-silica and GluBSUA-silica columns measured by AAS are presented in Fig. 3 .

As seen in Fig. 3, binding capacities of $\mathrm{Cu}^{2+}$ on multidentate ligand bonded-silica columns were related to the dentate number of ligands. Binding capacities of $\mathrm{Cu}^{2+}$ increased with an increase in the dentate number of ligands. Binding capacities of $\mathrm{Cu}^{2+}$ on quinquedentate Glu-BSUA-silica column was maximum, and was $23.21 \mu \mathrm{mol} / \mathrm{g}$ silica. However, binding capacities of $\mathrm{Cu}^{2+}$ on tridentate Glu-silica column was minimum, and was 11.57 $\mu \mathrm{mol} / \mathrm{g}$ silica.

Leakage of $\mathrm{Cu}^{2+}$ on multidentate chelate columns. As shown in Fig. 4, metal chelating stationary phase consists of immobilized metal $\mathrm{Cu}^{2+}$, silica matrix and chelating ligand. Chelating ligand is attached to silica via spacer arm. As introducing $\mathrm{Cu}^{2+}$ to naked column, coordination atoms can form chelate adsorbent with $\mathrm{Cu}^{2+}$ through coordination role. The adsorption of protein is attributed to the formation of coordination bond between immobilized $\mathrm{Cu}^{2+}$ and coordination atoms from histidine resi- (a)

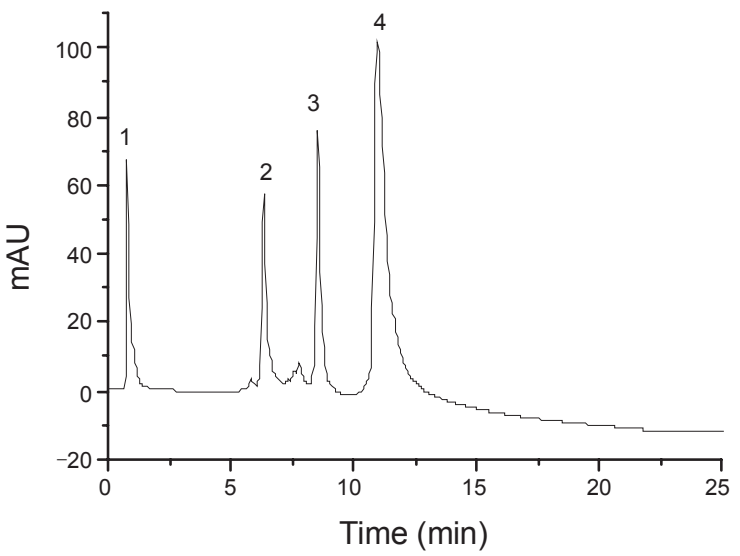

(b)

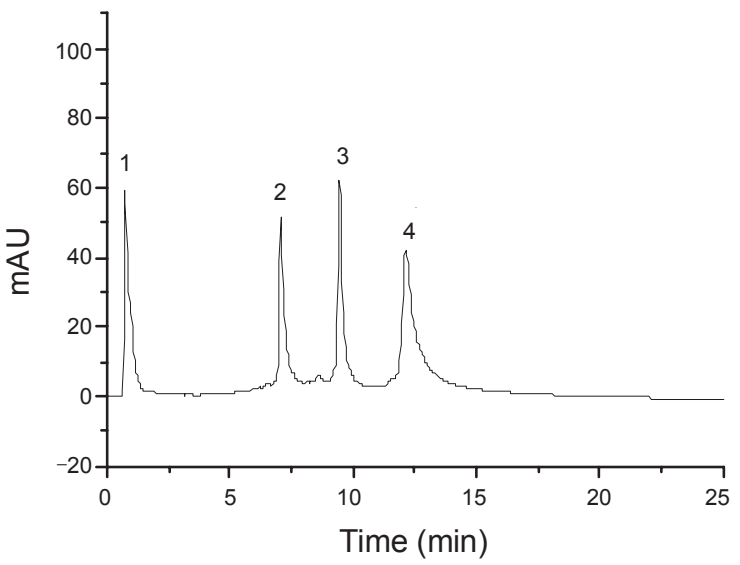

(c)

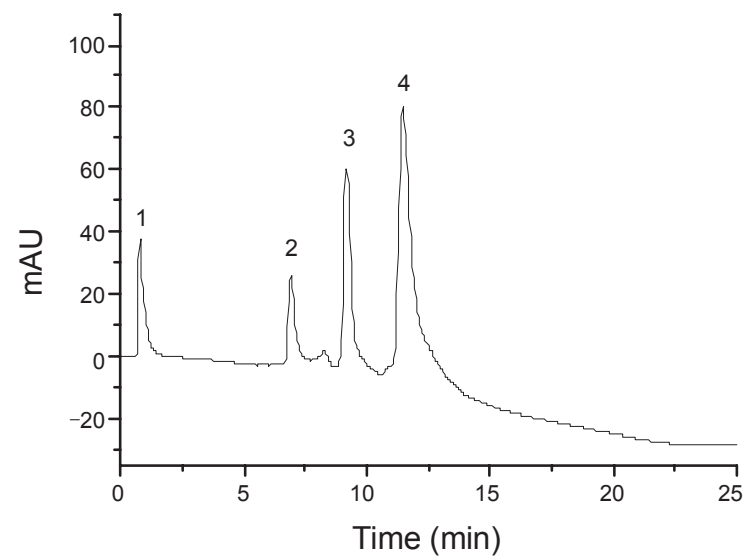

Figure 1. Chromatograms of proteins on multidentate ligand bondedsilica columns. 1, BSA; 2, RNase; 3, Cyt-C; 4, Lys. Columns, (a) Glusilica column; (b) Glu-BAA-silica column; (c) Glu-BSUA-silica column. Mobile phase, A 0.02 M PB (pH 6.0); B $0.02 \mathrm{M} \mathrm{PB}+0.5 \mathrm{M} \mathrm{NaCl}$ (pH 6.0). Gradient elution, B from 0 to $100 \%$ in $20 \mathrm{~min}$. Flow rate, $1 \mathrm{~mL} / \mathrm{min}$. Detector, UV (280 nm). Size of sample, $5 \mu \mathrm{L}$. Concentration of each protein, $2 \mathrm{mg} / \mathrm{mL}$.

dues on protein surface, e.g., nitrogen atom on Imid. Absorbed protein on metal chelate $\mathrm{Cu}$ (II) column usually can not be eluted with PB, but only by competitive elution. ${ }^{1}$

During the competitive elution, it is possible to cause the leakage of $\mathrm{Cu}^{2+}$ if the coordination role of competitive agent with $\mathrm{Cu}^{2+}$ is greater than that of multidentate ligand with $\mathrm{Cu}^{2+}$. Based on molecular structure and multidentate chelating me- 


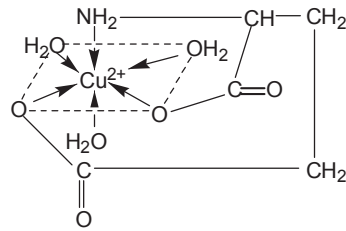

Glu-Cu' ${ }^{2+}$

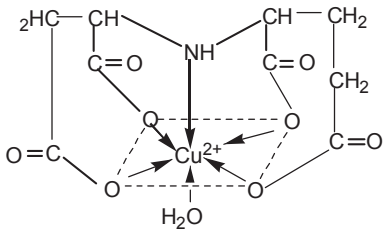

Glu-BSUA-Cu ${ }^{2+}$

Figure 2. Coordination schematic diagrams of multidentate ligands with $\mathrm{Cu}^{2+}$.

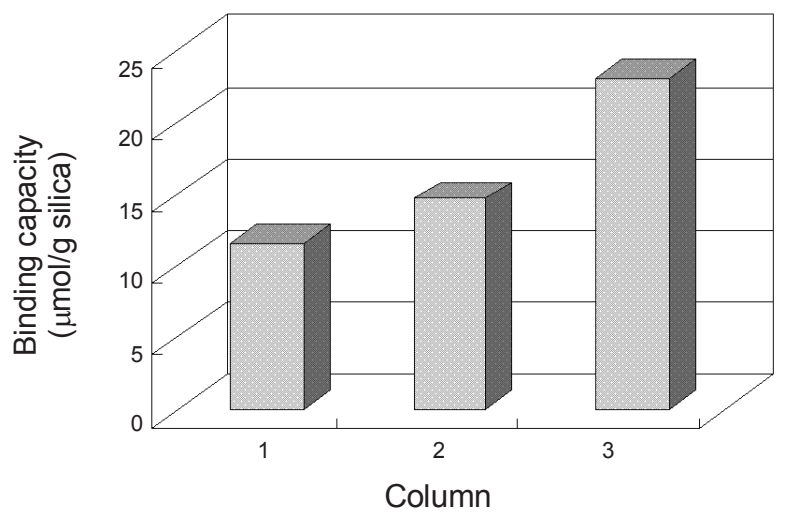

Figure 3. Effect of the dentate number of ligands on $\mathrm{Cu}^{2+}$ binding capacities. 1, Glu-silica column; 2, Glu-BAA-silica column; 3, GluBSUA-silica column.

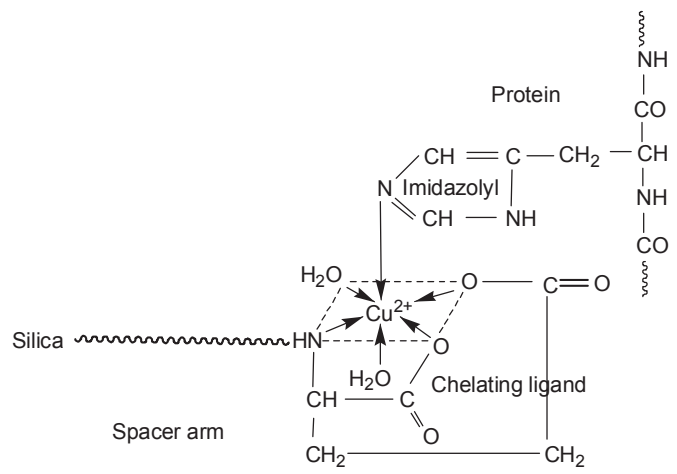

Figure 4. Coordination schematic diagram of $\mathrm{Cu}^{2+}$-Glu-silica with protein.

chanism, we deduce that the more the dentate number of multidentate ligand, the more stable is metal chelate formed with $\mathrm{Cu}^{2+}$, and then the more difficult is the leakage of $\mathrm{Cu}^{2+}$. To

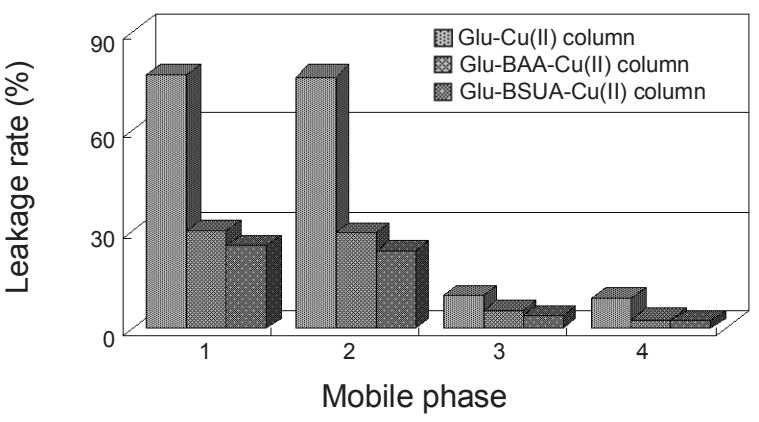

Figure 5. Leakage rates of $\mathrm{Cu}^{2+}$ on multidentate chelate $\mathrm{Cu}$ (II) columns in different competitive elution systems. Mobile phase 1, A $20 \mathrm{mM}$ $\mathrm{PB}+0.5 \mathrm{M} \mathrm{NaCl}+1 \mathrm{mM} \mathrm{Gly} ; \mathrm{B} 20 \mathrm{mM} \mathrm{PB}+0.5 \mathrm{M} \mathrm{NaCl}+40 \mathrm{mM}$ Gly (pH 6.0). Mobile phase 2, A $20 \mathrm{mM} \mathrm{NaAc}+0.5 \mathrm{M} \mathrm{NaCl}+1 \mathrm{mM}$ Gly; B $20 \mathrm{mM} \mathrm{NaAc}+0.5 \mathrm{M} \mathrm{NaCl}+40 \mathrm{mM}$ Gly (pH 6.0). Mobile phase 3, A $20 \mathrm{mM} \mathrm{PB}+0.5 \mathrm{M} \mathrm{NaCl}+1 \mathrm{mM}$ Imid; B $20 \mathrm{mM} \mathrm{PB}+0.5$ $\mathrm{M} \mathrm{NaCl}+40 \mathrm{mM}$ Imid (pH 6.0). Mobile phase 4, A $20 \mathrm{mM} \mathrm{NaAc}+$ $0.5 \mathrm{M} \mathrm{NaCl}+1 \mathrm{mM}$ Imid; B $20 \mathrm{mM} \mathrm{NaAc}+0.5 \mathrm{M} \mathrm{NaCl}+40 \mathrm{mM}$ Imid ( $\mathrm{pH}$ 6.0). Other conditions are the same as in Fig. 1.

confirm above viewpoint, the leakage rates of $\mathrm{Cu}^{2+}$ on chelating ligands with different dentate numbers were investigated under four kinds of different competitive systems, respectively. The experimental results are presented in Fig. 5.

It can be seen from Fig. 5 that: (1) Selecting Imid as competitive agent, the leakage rates of $\mathrm{Cu}^{2+}$ on three kinds of chelating ligands with different dentate numbers were significantly lowered both in PB and NaAc buffer systems as compared with Gly competitive agent. The result indicates that Gly had stronger competitive affinity for $\mathrm{Cu}^{2+}$ in comparison with Imid. This is since the stability constants of Gly with $\mathrm{Cu}^{2+}(\operatorname{lg~k}$ ' $8.08,7.24)^{27}$ are obviously greater than those of Imide with $\mathrm{Cu}^{2+}\left(\operatorname{lg~k}{ }^{\prime} 4.13,3.48\right){ }^{28}$ (2) No matter what kinds of buffer systems and competitive agents were adopted, the leakage rates of metal $\mathrm{Cu}^{2+}$ decreased with an increase in the dentate number of ligand. This means that the stability of coordination compound enhances with an increase in coordination atom numbers for the same kind of ligand.

Separation of proteins on multidentate stationary phases. As proteins are separated with multidentate chelate $\mathrm{Cu}(\mathrm{II})$ column, the choice of separation conditions should meet two requirements: 1) Adsorbed proteins on chelate $\mathrm{Cu}(\mathrm{II})$ column should be efficiently eluted and separated. 2) the leakage of $\mathrm{Cu}^{2+}$ should be as low as possible. Therefore, the choice of operating conditions should start with stationary phases, competitive agents and the concentration of agents. Gly and Imid are the commonly used competitive agents. The previous experiment showed that Gly had stronger competitive affinity for $\mathrm{Cu}^{2+}$ in comparison with Imid (Fig. 5). It was difficult to control the concentration of Gly. Proteins were not easily eluted with the low concentration of Gly. On the other hand, the leakage of $\mathrm{Cu}^{2+}$ became serious at higher concentration of Gly. Consequently, Imid with more moderate affinity for $\mathrm{Cu}^{2+}$ was selected for competitive agent. Chromatograms of proteins on Glu$\mathrm{Cu}$ (II), Glu-BAA-Cu(II) and Glu-BSUA-Cu(II) columns in different competitive elution systems are given in Fig. 6. It can be seen from Fig. 6 that: using $20 \mathrm{mM}$ Imid as competitive agent, four kinds of proteins adsorbed on tridentate $\mathrm{Glu}-\mathrm{Cu}$ (II) 
(a)
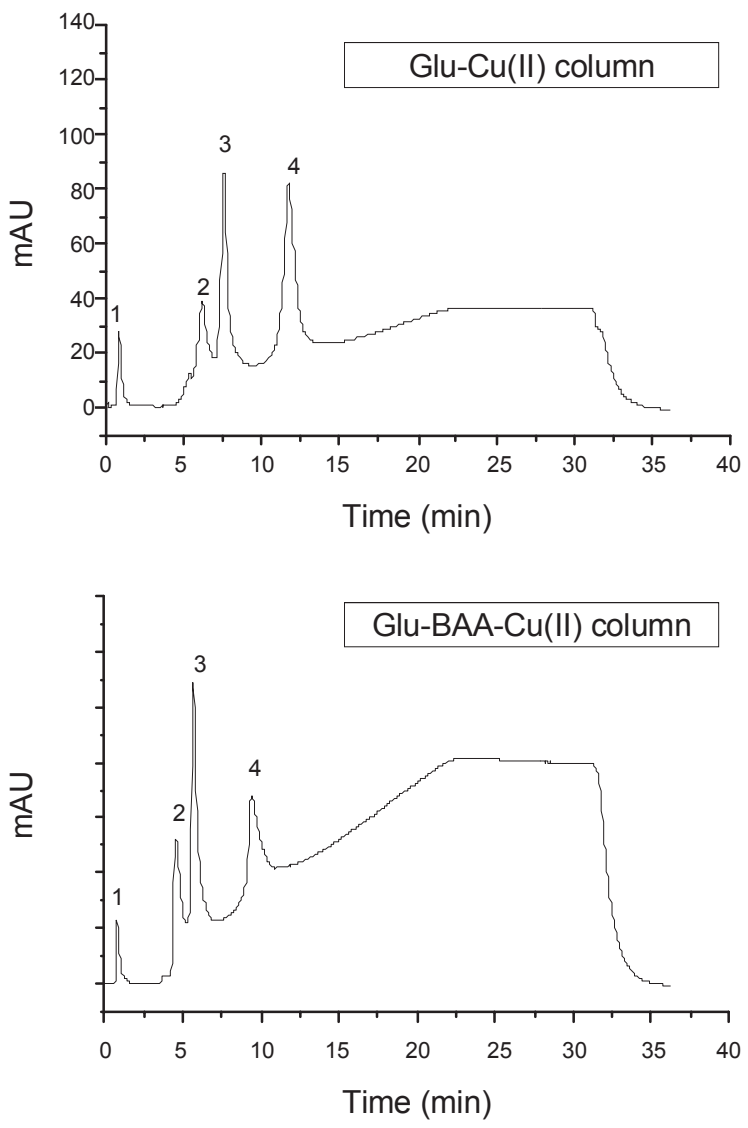

(c)

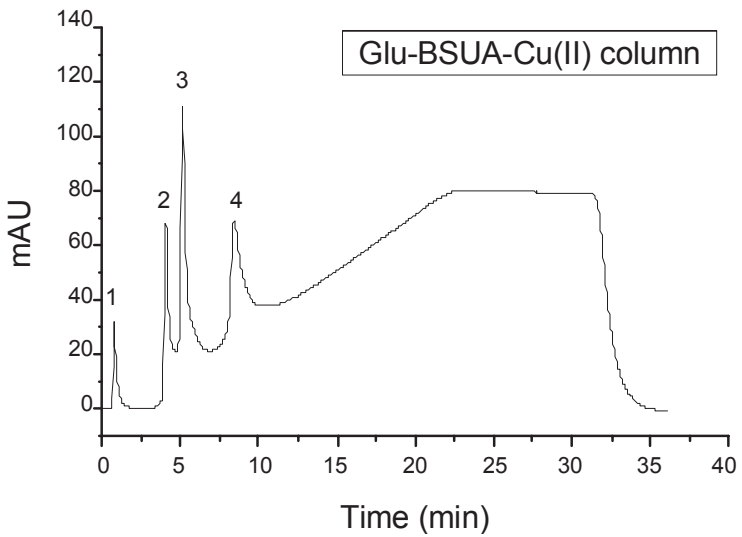

Figure 6. Chromatograms of proteins on multidentate chelate $\mathrm{Cu}$ (II) columns in different competitive elution systems. 1, BSA; 2, RNase; 3, Cyt-C; 4, Lys. (a) A: $20 \mathrm{mM} \mathrm{PB}+0.05 \mathrm{M} \mathrm{NaCl}$; B: $20 \mathrm{mM} \mathrm{PB}+$ $0.5 \mathrm{M} \mathrm{NaCl}+20 \mathrm{mM}$ Imid (pH 6.0). (b)-(c), A: $20 \mathrm{mM} \mathrm{PB}+0.05 \mathrm{M}$ $\mathrm{NaCl}$; B: $20 \mathrm{mM} \mathrm{PB}+0.5 \mathrm{M} \mathrm{NaCl}+40 \mathrm{mM}$ Imid (pH 6.0). Other conditions are the same as in Fig. 1

column were effectively separated and the leakage rate of $\mathrm{Cu}^{2+}$ was $6.96 \%$, which did not affect detection. However, RNase and Cyt-C on tetradentate Glu-BAA-Cu(II) and quinquedentate Glu-BSUA-Cu(II) columns were incompletely isolated due to the stronger adsorption of these two columns for proteins (Figure omitted). Only if the concentration of Imid was increased to $40 \mathrm{mM}$, these two kinds of proteins adsorbed on tetradentate and quinquedentate $\mathrm{Cu}(\mathrm{II})$ columns could be effectively separated. At this concentration, the leakage rates of $\mathrm{Cu}^{2+}$ on Glu-BAA-
$\mathrm{Cu}$ (II) and Glu-BSUA-Cu(II) columns were 5.28\% and 4.08\%, respectively. Thus, chelate $\mathrm{Cu}$ (II) columns with different dentate numbers all had their own optimum separation conditions. In view of separating efficiency and the leakage rate of $\mathrm{Cu}^{2+}$, quinquedentate Glu-BSUA-Cu(II) column exhibited better chromatographic property as compared with tridentate $\mathrm{Glu}-\mathrm{Cu}(\mathrm{II})$ and tetradentate Glu-BAA-Cu(II) columns. In addition, separation performance of proteins and the leakage rate of $\mathrm{Cu}^{2+}$ on Glu-BSUA-Cu(II) column were also compared with traditional IDA-Cu(II) column. The results indicated that: under the same chromatographic condition, adsorbed proteins on IDA-Cu(II) column could not be effectively eluted and isolated (Figure omitted). The leakage rate of $\mathrm{Cu}^{2+}$ on IDA-Cu(II) column was $6.83 \%$, which was higher than that on Glu-BSUA-Cu(II) column. Although the elution and separation of proteins on IDA$\mathrm{Cu}(\mathrm{II})$ column could be slightly improved by increasing the concentration of Imid, the leakage rate of $\mathrm{Cu}^{2+}$ was significantly higher. The above results proved that quinquedentate GluBSUA is a valuable stationary phase.

\section{Conclusion}

Multidentate Glu-silica, Glu-BAA-silica and Glu-BSUAsilica columns with cation-exchange characteristics were prepared, and successfully used for the separation of proteins. Silica gel columns with multidentate ligands had chelate properties for $\mathrm{Cu}^{2+}$. The binding capacity of $\mathrm{Cu}^{2+}$ increased with an increase in the dentate number of ligands. The leakage of $\mathrm{Cu}^{2+}$ decreased with an increase in the dentate number of ligands, and was related to the strength of competitive elution systems. Three chelate $\mathrm{Cu}$ (II) columns with different dentate numbers all could be applied to the isolation of proteins under the competitive elution. The experiment proved that Glu-BSUA-Cu(II) column has better separation property and lower leakage rate of $\mathrm{Cu}^{2+}$.

In summary, besides the leakage of $\mathrm{Cu}^{2+}$, the separation effect of proteins on chelate column also should be taken into account for selecting the metal chelate ligand with appropriate dentate number. These studies may provide reference values for selecting and exploring the novel chelate ligands, improving the separation efficiency of proteins on metal chelate columns, reducing the leakage of immobilized metal copper ion (II) and the pollution of heavy metal in the process of protein separations and purifications.

Acknowledgments. This work was supported by grants from Natural Science Foundation of Shaanxi Province (No. 2007B22), Natural Science Fund of Shaanxi Provincial Education Department (N0. 09JK758), Shannxi Provincial Key Discipline Program and Scientific Research Foundation for the Master Program of Northwest University (No. 09YSY24).

\section{References}

1. Wang, Y.; Li, R.; Chen, G. L.; Wang, X. G. Chin. J. Chem. 2008, 11,838 .

2. Dursun, E.; Ozben, B.; Monari, E.; Cuoghi, A.; Tomasi, A.; Ozben, T. Acta Histochem. 2010, 112, 178. 
3. Dedieu, A.; Bérenguer, F.; Basset, C.; Prat, O.; Quéméneur, E.; Pible, O.; Vidaud, C. J. Chromatogr. A 2009, 1216, 5365.

4. Kulathingal, J.; Ko, L. W.; Cusack, B.; Yen, S. H. Biochim. Biophys. Acta-Proteins Proteomics 2009, 1794, 211.

5. Fang, X. M.; Zhang, W. W. J. Proteomics 2008, 71, 284.

6. Dong, X. Y.; Chen, L. J.; Sun, Y. J. Chromatogr. A 2009, 1216, 5207.

7. Kosobokova, E.; Kosorukov, V. New Biotechnol. 2009, 25, 179.

8. Abe, R.; Kudou, M.; Tanaka, Y.; Arakawa, T.; Tsumoto, K. Biochem. Biophys. Res. Commun. 2009, 381, 306.

9. Wang, C. Z.; Wang, L. L.; Geng, X. D. Biochem. Eng. J. 2009, 43, 197.

10. Maja, K.; Vladka, G. P.; Irena, F.; Viktor, M. J. Chromatogr. B 2008, 867, 119.

11. Moon, W. J.; Hwang, D. K.; Park, E. J.; Kim, Y. M.; Chae, Y. K. Protein Expres. Purif. 2007, 51, 141.

12. Liang, X. Q.; Fonnum, G.; Hajivandi, M.; Stene, T.; Kjus, N. H.; Ragnhildstveit, E.; Amshey, J. W.; Predki, P.; Pope, R. M. J. Am. Soc. Mass Spectrom. 2007, 18, 1932.

13. Yu, Z. Y.; Han, G. H.; Sun, S. T.; Jiang, X. N.; Chen, R.; Wang, F. J.; Wu, R. A.; Ye, M. L.; Zou, H. F. Anal. Chim. Acta 2009, 636, 34.

14. Callesen, A. K.; Vach, W.; Jorgensen, P. E.; Cold, S.; Tan, Q. H.; Rene, D. P. C.; Mogensen, O.; Kruse, T. A.; Jensen, O. N.; Madsen, J. S. J. Proteome Res. 2008, 7, 1419.

15. Lee, Y. M.; Venkataraman, K.; Hwang, S.; Han, D. K.; Hla, T. Pro staglandins Other Lipid Mediat. 2007, 84, 154.

16. Fung, E. T.; Ueland, F. R.; Van, N. J. R.; Depriest, P. D.; Baron, A. T. PCT Int. Appl. 2007, 58.

17. Pessela, B. C. C.; Mateo, C.; Filho, M.; Carrascosa, A.; Fernandez, L. R.; Guisan, J. M. Enzyme Microb. Technol. 2007, 40, 242.

18. Victor, M. B. G.; Owen, R. D. Biochem. Biophy. Acta 2006, 1760, 1304.

19. Oshima, T.; Kanemaru, K.; Tachiyama, H.; Ohe, K.; Baba, Y. J. Chromatogr. B 2008, 876, 116.

20. Jiang, W.; Prescott, M.; Devenish, R. J.; Spiccia, L.; Hearn, M. T. W. Biotechnol. Bioeng. 2009, 103, 747.

21. Knecht, S.; Ricklin, D.; Eberle, A. N.; Ernst, B. J. Mol. Recognit. 2009, 22, 270.

22. Roque, A. C. A.; Silva, C. S. O.; Taipa, M. J. Chromatogr. A 2007, 1160,44

23. Dévédec, F. L.; Bazinet, L.; Furtos, A.; Venne, K.; Brunet, S.; Mateescu, M. A. J. Chromatogr. A 2008, 1194, 165.

24. Gutierrez, R.; Del Valle, E. M. M.; Galan, M. A. Sep. Purif. Rev. 2007, 36, 71 .

25. Ueda, E. K. M.; Gout, P. W.; Morganti, L. J. Chromatogr. A 2003 , 988, 1.

26. Li, R.; Chen, G. L.; Zhao, W. M. Annali. Di. Chimica. 2004, 94, 939.

27. Fan, J. Talanta 1995, 42, 317.

28. Kapinos, L. E.; Song, B.; Sigel, H. Inorg. Chim. Acta 1998, $280,50$. 